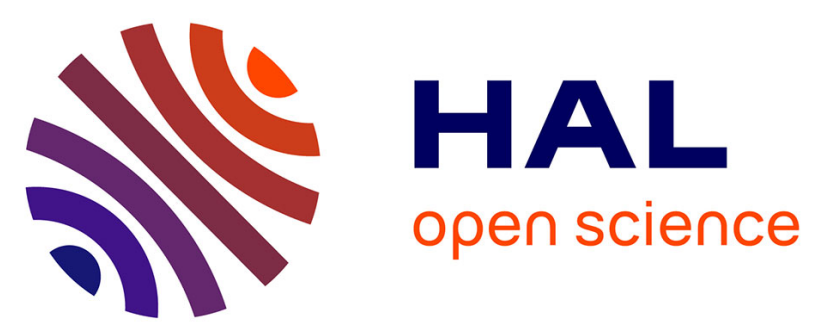

\title{
Phoma stem canker (Leptosphaeria maculans/L. biglobosa) of oilseed rape (Brassica napus) : is the G2 disease index a good indicator of the distribution of observed canker severities?
}

Elise Pelzer, Jean-Noel Aubertot, Lydia Bousset, Xavier Pinochet, Marie-Helene Jeuffroy

\section{To cite this version:}

Elise Pelzer, Jean-Noel Aubertot, Lydia Bousset, Xavier Pinochet, Marie-Helene Jeuffroy. Phoma stem canker (Leptosphaeria maculans/L. biglobosa) of oilseed rape (Brassica napus) : is the G2 disease index a good indicator of the distribution of observed canker severities?. European Journal of Plant Pathology, 2009, 125 (4), pp.515-522. 10.1007/s10658-009-9499-y . hal-01173181

\author{
HAL Id: hal-01173181 \\ https://hal.science/hal-01173181
}

Submitted on 30 May 2020

HAL is a multi-disciplinary open access archive for the deposit and dissemination of scientific research documents, whether they are published or not. The documents may come from teaching and research institutions in France or abroad, or from public or private research centers.
L'archive ouverte pluridisciplinaire HAL, est destinée au dépôt et à la diffusion de documents scientifiques de niveau recherche, publiés ou non, émanant des établissements d'enseignement et de recherche français ou étrangers, des laboratoires publics ou privés.

$$
\text { Copyright }
$$


Phoma stem canker (Leptosphaeria maculans/L. biglobosa) of oilseed rape (Brassica napus): is the G2 Disease Index a good indicator of the distribution of observed canker severities?

\author{
Lô-Pelzer E ${ }^{\mathrm{a}}$, Aubertot JN ${ }^{\mathrm{b}}$, Bousset L ${ }^{\mathrm{c}}$, Pinochet $\mathrm{X}^{\mathrm{d}}$, Jeuffroy $\mathrm{MH}^{\mathrm{a}}$
}

aINRA AgroParisTech, UMR211 Agronomie, BP01, 78850 Thiverval-Grignon, France

bINRA, ENSAT, UMR 1248 AGIR, BP 52627 Auzeville, 31326 Castanet Tolosan, France

cINRA, Agrocampus Rennes, UMR1099 BiO3P (Biology of Organisms and Populations applied to Plant

Protection), 35653 Le Rheu, France

dCETIOM, BP04, 78850 Thiverval-Grignon, France

\begin{abstract}
Several disease indices (DI) have been proposed to assess the severity of phoma stem canker at late growth stages. The DI commonly used in France (called $\mathrm{G}_{2}$ DI) consists of integrating the distribution of the proportions of plants observed within six canker severity classes into a single index. This index uses arbitrarily chosen coefficients associated to each class of canker severity. A given value of this DI can therefore be obtained with different distributions among the canker severity classes. Consequently, it is important to assess to what extent the $\mathrm{G}_{2} \mathrm{DI}$ is representative of the distribution of plants in canker severity classes. We show in this study that the $\mathrm{G}_{2}$ DI is a good indicator of the distribution of the observed canker severities, using a dataset from different years, sites and cultivars; this illustrates the robustness of the $\mathrm{G}_{2} \mathrm{DI}$.
\end{abstract}

Keywords: Blackleg, Canola, Disease index, Distribution, Phytopathometry

\title{
Introduction
}

Phoma stem canker, caused by the species complex Leptosphaeria maculans/L. biglobosa, is one of the most important diseases of oilseed rape (Brassica napus). This disease has a major economic impact, with significant yield losses (West et al. 2001). Leaf spots appear on leaves after infections by ascospores, the primary inoculum. Secondary infections can occur on adjacent plants through rain-dispersed conidia (Hall 1992). There is a systemic progression of the fungus from leaves to the base of the stem where the second symptom, the canker (or necrosis), appears (West et al. 2001). When plants are infected before the 6-leaf stage, cankers can be responsible for high yield losses, as it hinders mineral and water nutrition of the plant (Brunin and Lacoste 1970). Several methods can be used to control the disease, such as use of resistant cultivars, adaptation of cultural practices (particularly tillage that limits the quantity of primary inoculum by burying stubble) and fungicide treatments (Aubertot et al. 2006). As the disease can cause high yield loss, it is important to be able to assess the severity of the disease at various growth stages. To give advice on fungicide treatments, early assessment of leaf spotting is necessary. On the other hand, yield loss prediction or cultivar resistance evaluation necessitates late assessment of canker severity. Canker severity assessment is required to understand the epidemic cycle of the disease, and the subsequent crop losses.

Several proposals have been made in the literature to assess the severity of phoma stem canker at late growth stages. McGee (1973) proposed sampling plants at flowering or at harvest in 20 equally spaced spots $(30 \mathrm{~cm}$ diam) in a diagonal line across the field and to sort the plants in three classes: healthy plants, and slightly or severely stem base cankered plants. Unfortunately, he did not provide any details on where on the stem and how the severity of cankers was assessed (section of the stem or external assessment). A disease index (DI) was calculated at flowering as the percentage of cankered plants of a given field, or at harvest as the percentage of severely cankered plants. Van den Berg et al. (1993) compared different assessments of severity and showed that rating the area of diseased tissue at the base of the stem was the most reliable. Rempel and Hall (1996) proposed assessing disease severity on 100 plants, picked randomly in the field, by cutting them at the base of the stem and by sorting cankers in five classes ( 0 to 4$)$ of canker severity according to the area of the cross-section that is discoloured by the disease $(0 \%, 1-25 \%, 26-50 \%, 51-75 \%$ and $76-100 \%)$. The DI is calculated as follows: 


$$
D I=\frac{\sum_{i=0}^{4} i * n_{i}}{4 * \sum_{i=0}^{4} n_{i}} * 100
$$

Where $n_{i}$ is the number of plants in class of severity of canker $i$. Values of this DI range from $0 \%$ to $100 \%$.

These authors advised assessing the canker severity at the end of flowering (growth stage 4.4: flowering complete, seeds enlarging at lower pods; Harper and Berkenkamp 1975).

The most commonly used Disease Index in France, called $\mathrm{G}_{2}$ DI, is based on a classification of plants in six classes of canker severity, from healthy plants to lodged plants. This classification was first proposed by Pierre and Regnault (1982) who recommended assessing the severity of canker one month before harvest. Based on this, Aubertot et al. (2004a) conducted a methodological study on the assessment of stem canker disease severity. A comparison of several methods to assess canker severity was performed: plant assessment after scraping the circumference of the crown, plant assessment after scraping and sectioning at crown level, visual assessment of the crown circumference, and plant assessment after sectioning the plant at crown level. Two scales were defined, for circumference (scraping and visual) and crown section assessment. At crop maturity (growth stage 5.3-5.5: seeds green-brown to brown in the lowest pods; Harper and Berkenkamp 1975), canker severity assessed on the section of the stem at crown level, was shown to be the most precise method between those compared by Aubertot et al. (2004a). A more precise definition of the severity classes was proposed: 1 , healthy plants, no visible lesion; 2 , canker weakly developed ( $<25 \%$ of necrosed section); 3 , canker developed on $>25 \%$ but $<50 \%$ of the crown section; 4 , canker developed on $>50 \%$ of the crown section but $<75 \%$ of the crown section; 5 , canker almost developed on the whole crown section ( $>75 \%$ of necrosed section) and 6, section without any living tissue, plant lodged or broken at the crown level during sampling. Among and within rater repeatability of the assessment was also studied. The new Disease Index derived from Pierre and Regnault (1982), called G2 DI, is calculated as follows:

$$
D I=\frac{\sum_{i=2}^{6}[2(i-2)+1] n_{i}}{\sum_{i=1}^{6} n_{i}}
$$

Where $n_{i}$ is the number of plants in class of severity of canker $i$.

The $G_{2}$ DI ranges between 0 (healthy plants) to 9 (all plants totally cankered). Aubertot et al. (2004a) also proposed a method to determine the sample size as a function of the precision required on the $\mathrm{G}_{2} \mathrm{DI}$, as well as the sampling scheme given spatial structure of the disease within fields. The G2 DI is strongly correlated with yield losses (Aubertot et al. 2004b).

Lô-Pelzer et al. (2008) developed a model called SIPPOM-WOSR, a Simulator for Pathogen Population Management adapted to phoma stem canker on Winter Oil Seed Rape. The model simulates the effect of cropping systems and their spatial distribution on phoma stem canker. In order to propose strategies for control of the disease at regional scales and over several years, it was necessary to represent the recurrence of the epidemics, i.e. the link between the disease severity and the subsequent quantity of ascospores produced for the next year epidemics. Lô-Pelzer et al. (2009) have shown that the quantity of pseudothecia produced on stubble increases with canker severity assessed as defined by Aubertot et al. (2004a), and the relationship between canker severity and quantity of primary inoculum was used in SIPPOM. The infection sub-model used in SIPPOM (Aubertot et al. 2004b) directly simulates the G2 DI from the number of leaf-spots, without simulating the canker severity on individual plants. In order to link the infection sub-model and the production of inoculum on individual plants, it was therefore necessary to determine the distribution of plants in each canker severity given the G2 DI simulated by the infection sub-model. However, a single value of the DI can be obtained with various distributions of symptoms. For instance, Aubertot et al. (2004a) presented two different hypothetic distributions leading to the same value of $\mathrm{G}_{2}$ DI of 4.5 : distribution $1:(0.03 ; 0.07 ; 0.15$; $0.67 ; 0.05 ; 0.03)$, or $3 \%$ of plants with canker severity $1,7 \%$ of plants with canker severity $2,15 \%$ of plants with canker severity $3,67 \%$ of plants with canker severity $4,5 \%$ of plants with canker severity $5,3 \%$ of plants with canker severity 6 ; distribution $2:(0.02 ; 0.27 ; 0.13 ; 0.28 ; 0.15 ; 0.15)$. 
The main aim of this study was to analyse if close $\mathrm{G}_{2}$ DI values emerged from close divisions of plants into the canker severity classes, or if data collected in fields showing totally different plant partitioning in the canker severity classes could lead to close G2 DI values. This index would therefore not only be appropriate to get an average image of the disease at the field scale, but would also be representative of a distribution of plants among the canker severity classes. And the divisions of plants into the canker severity classes depending on the G2 DI values could be used in SIPPOM-WOSR. To compare the G2 DI to other indices, the distribution of plants in canker severity classes was also analysed for two other disease indices.

\section{Materials and methods}

\section{Data collection}

Forty plants per plot in 284 plots in the experimental sites of Grignon $\left(48.9^{\circ} \mathrm{N}, 1.9^{\circ} \mathrm{E}, 130 \mathrm{~m}\right.$ elevation, Ilede-France), and Saint Florent sur Cher $\left(46.0^{\circ} \mathrm{N}, 2.0^{\circ} \mathrm{E}, 117 \mathrm{~m}\right.$ elevation, Cher), were assessed for canker severity at crop maturity (as described by Aubertot et al., 2004a), between 2002 and 2006. Fourteen cultivars were represented (Table 1). The number of assessed fields for each year and cultivar was between 4 and 12 (Table 1). The $\mathrm{G}_{2}$ DI was calculated for each field, and $9 \mathrm{G} 2$ DI-intervals were defined according to the value of the calculated G2 DI (Table 2). The proportions of plants in each class of severity (classes 1 to 6) leading to a given value of G2 DI, were termed 'distribution'. An example of the distributions obtained for the G2 DIInterval 8 is presented in Table 3 . The first distribution $(0 ; 0 ; 0.025 ; 0.125 ; 0.65 ; 0.2)$ means that $0 \%$ of the 40 plants in the corresponding plot have been noted with canker severity $1,0 \%$ have been noted with canker severity $2 ; 2.5 \%$ have been noted with canker severity $3,12.5 \%$ have been noted with canker severity $4,65 \%$ have been noted with canker severity 5 , and $20 \%$ have been noted with canker severity 6.

Table 1 Number of plots (40 plants per plot) assessed for phoma stem canker (Leptosphaeria maculans) severity (G2 DI) given the year and the winter oilseed rape cultivar (Brassica napus)

\begin{tabular}{llllll} 
Year & \multicolumn{7}{l}{} \\
\hline Cultivar & 2002 & 2003 & 2004 & 2005 & 2006 \\
Columbus & 8 & 4 & 4 & 8 & 12 \\
Eurol & 8 & 4 & 4 & 8 & 12 \\
Falcon & 8 & 4 & 4 & 8 & 12 \\
Goeland & 8 & 4 & 4 & 8 & 12 \\
Jet9 & 8 & 4 & 4 & 8 & 12 \\
Vivol & 8 & 4 & 4 & 8 & 12 \\
Aviso & 4 & 4 & 4 & 8 & 8 \\
Roxet & - & - & - & 8 & 8 \\
Nectar & - & - & - & - & 4 \\
Libri & - & - & - & - & 4 \\
Kadore & - & - & - & - & 4 \\
Hydromel & - & - & - & - & 4 \\
Hybristar & - & - & - & - & 4 \\
Barrel & - & - & - & - & 4 \\
\hline
\end{tabular}


Table 2 Number of distributions recorded in each G2 DI-interval

\begin{tabular}{lll}
\hline G2 DI-interval & G2 DI value & Number of distributions \\
\hline 1 & $0<\mathrm{G}_{2 \leq 1}$ & 20 \\
2 & $1<\mathrm{G}_{2 \leq 2}$ & 27 \\
3 & $2<\mathrm{G}_{2 \leq 3}$ & 72 \\
4 & $3<\mathrm{G}_{2 \leq}$ & 63 \\
5 & $4<\mathrm{G}_{2 \leq 5}$ & 42 \\
6 & $5<\mathrm{G}_{2 \leq 6}$ & 26 \\
7 & $6<\mathrm{G}_{2 \leq}$ & 18 \\
8 & $7<\mathrm{G}_{2 \leq} 8$ & 10 \\
9 & $8<\mathrm{G}_{2 \leq 9}$ & 6 \\
\hline
\end{tabular}

Table 3 Example of distributions of plants obtained for G2 DI values between 7 and 8 (G2 DI-interval 8). A distribution corresponds to the proportion of assessed plants that fall into in each canker severity class (as defined by Aubertot et al., 2004a) among the 40 plants assessed in each plot

\begin{tabular}{|c|c|c|c|c|c|c|c|}
\hline \multirow[t]{2}{*}{ Cultivar } & \multicolumn{7}{|c|}{ Proportion of plants } \\
\hline & $\begin{array}{l}\mathrm{G} 2 \\
\mathrm{DI}\end{array}$ & $\begin{array}{l}\text { with a canker } \\
\text { severity of } 1\end{array}$ & $\begin{array}{l}\text { with a canker } \\
\text { severity of } 2\end{array}$ & $\begin{array}{l}\text { with a canker } \\
\text { severity of } 3\end{array}$ & $\begin{array}{l}\text { with a canker } \\
\text { severity of } 4\end{array}$ & $\begin{array}{l}\text { with a canker } \\
\text { severity of } 5\end{array}$ & $\begin{array}{l}\text { with a canker } \\
\text { severity of } 6\end{array}$ \\
\hline Vivol & 7.05 & 0 & 0 & 0.025 & 0.125 & 0.650 & 0.200 \\
\hline Columbus & 7.28 & 0.025 & 0 & 0 & 0.150 & 0.450 & 0.375 \\
\hline Vivol & 7.3 & 0 & 0 & 0.05 & 0.050 & 0.600 & 0.300 \\
\hline Aviso & 7.4 & 0 & 0 & 0 & 0.075 & 0.650 & 0.275 \\
\hline Vivol & 7.6 & 0 & 0 & 0.050 & 0.150 & 0.250 & 0.550 \\
\hline Aviso & 7.65 & 0 & 0.025 & 0 & 0.100 & 0.375 & 0.500 \\
\hline Eurol & 7.75 & 0 & 0.025 & 0 & 0 & 0.525 & 0.450 \\
\hline Vivol & 7.75 & 0 & 0 & 0 & 0 & 0.625 & 0.375 \\
\hline Eurol & 7.9 & 0 & 0 & 0 & 0.025 & 0.500 & 0.475 \\
\hline Eurol & 7.95 & 0 & 0 & 0.025 & 0.100 & 0.250 & 0.625 \\
\hline $\begin{array}{l}\text { Mean } \\
\text { distribution }\end{array}$ & & 0.002 & 0.005 & 0.015 & 0.077 & 0.488 & 0.413 \\
\hline
\end{tabular}

\section{G2 DI analysis}

To test whether the $\mathrm{G}_{2}$ DI is a good indicator of the distribution of the observed canker severities, we compared, for each G2 DI-interval, each distribution against the average distribution for the considered interval. In order to avoid artificial correlation between the two compared distributions, the average distribution was calculated using all distributions of a given G2 DI-interval, except the one that was tested. This procedure was similar to cross-validation, as described by Wallach et al. (2006).

With the example presented in Table 3 , the first distribution $(0 ; 0 ; 0.025 ; 0.125 ; 0.65 ; 0.2)$ was compared with the average distribution $(0.003 ; 0.006 ; 0.0139 ; 0.072 ; 0.469 ; 0.436)$, each proportion of this average distribution being the average of the 9 proportions of the corresponding canker severity class of other distributions: 0.469 , for instance, corresponds to the class 5 , and

$$
0.469=\frac{0.450+0.600+0.650+0.250+0.375+0.525+0.625+0.500+0.250}{9}
$$

The tested distributions were compared with the corresponding average distributions, using the nonparametric Kolmogorov-Smirnov test (procedure NPAR1WAY, SAS ${ }^{\circledR}$ ). With the Kolmogorov-Smirnov test, 
the hypothesis tested is $\mathrm{H}_{0}$ : the distributions are significantly different. By calculating the average distribution independently from the tested distribution, the independence of the two compared distributions in a Kolmogorov-Smirnov test was respected.

Mean distributions were then calculated with all distributions of each G2 DI-interval. For the example presented in Table 3 , the mean distribution $(0.0025 ; 0.005 ; 0.015 ; 0.0775 ; 0.4875 ; 0.4125)$ corresponds to the average of the 10 distributions of the G2 DI-interval 8. For instance, 0.488 corresponds to the canker severity class 5 , and

$$
0.488=\frac{0.650+0.450+0.600+0.650+0.250+0.375+0.525+0.625+0.500+0.250}{10}
$$

Mean distributions were compared between G2 DI-intervals using the same statistical test.

\section{Comparison with other severity disease indices}

The same study was performed with the index proposed by Rempel and Hall (1996), $\mathrm{DI}_{\mathrm{RH}}$, and with a simpler index being the mean of the canker severities (noted on plants as defined by Aubertot et al., 2004a), DIMean:

$$
D I_{R H}=\frac{\sum_{i=0}^{4} i * n_{i}}{4 * \sum_{i=0}^{4} n_{i}} * 100 \text { and } D I_{\text {Mean }}=\frac{\sum_{i=0}^{4} i * n_{i}}{\sum_{i=0}^{4} n_{i}}
$$

Where $n_{i}$ is the number of plants in class of severity of canker $i$.

Values of the $\mathrm{DI}_{\mathrm{RH}}$ defined by Rempel and Hall (1996) range from 0 to 100 . Ten $\mathrm{DI}_{\mathrm{RH}}$-intervals were chosen: [0; 10[, [10; 20[, [20;30[, [30; 40[, [40; 50[, [50;60[, [60; 70[, [70; 80[, [80; 90[, and [90; 100]. For first and middle intervals [0;10[ and [50;60[, distributions were compared with their average distribution using the same statistical test.

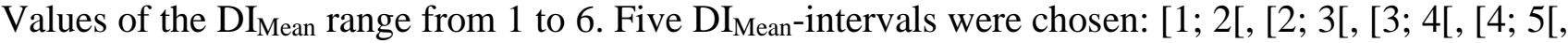
and $[5 ; 6]$. For first and middle intervals $[1 ; 2[$ and $[3 ; 4[$, distributions were compared with their average distribution using the same statistical test.

\section{Results}

\section{G2 DI analysis}

The number of distributions in each G2 DI-interval, all years and cultivars confounded, was between 6 (interval 9) and 72 (interval 3; Table 2). The distributions and the mean distributions (represented here as proportions of plants in each canker severity class) for each G2 DI-interval are shown in Fig. 1.

With a threshold of $P=0.05$, only two distributions were significantly different from the corresponding average distribution in G2 DI-intervals 6 and 9 (26 and 6 considered distributions, Table 2). Other distributions in these G2 DI-intervals, and all distributions in other G2 DI-intervals were not significantly different from the associated average distributions. With $P=0.10$, one distribution in G2 DI-intervals 1, 2, 3, 5 (20, 27, 72 and 42 considered distributions, Table 2), and three distributions in G2 DI-interval 4 (63 considered distributions) were significantly different from the average distribution (in addition to previous distributions for $P=0.05)$.

Mean distributions (Fig. 2), calculated with all distributions, were significantly different between G2 DI intervals, except for distributions from two successive DI-intervals: the mean distribution of the G2 DIinterval 2 was not significantly different of the mean distribution of the G2 DI-intervals 1 and 3 but significantly different of all the other mean distributions, the mean distribution of the G2 DI-interval 3 was not significantly different of the mean distribution of the G2 DI-intervals 2 and 4 but significantly different of the other mean distributions, and so on. This indicates that each calculated mean distribution was representative of the considered DI-interval and that the definition and number of G2 DI-intervals was appropriate. 
Fig. 1 Distributions and mean distribution (thick black line) for the different G2 DI-intervals (Table 2): the distributions represent the proportion of plants of winter oilseed rape (among the 40 noted plants per plot) in each canker severity class

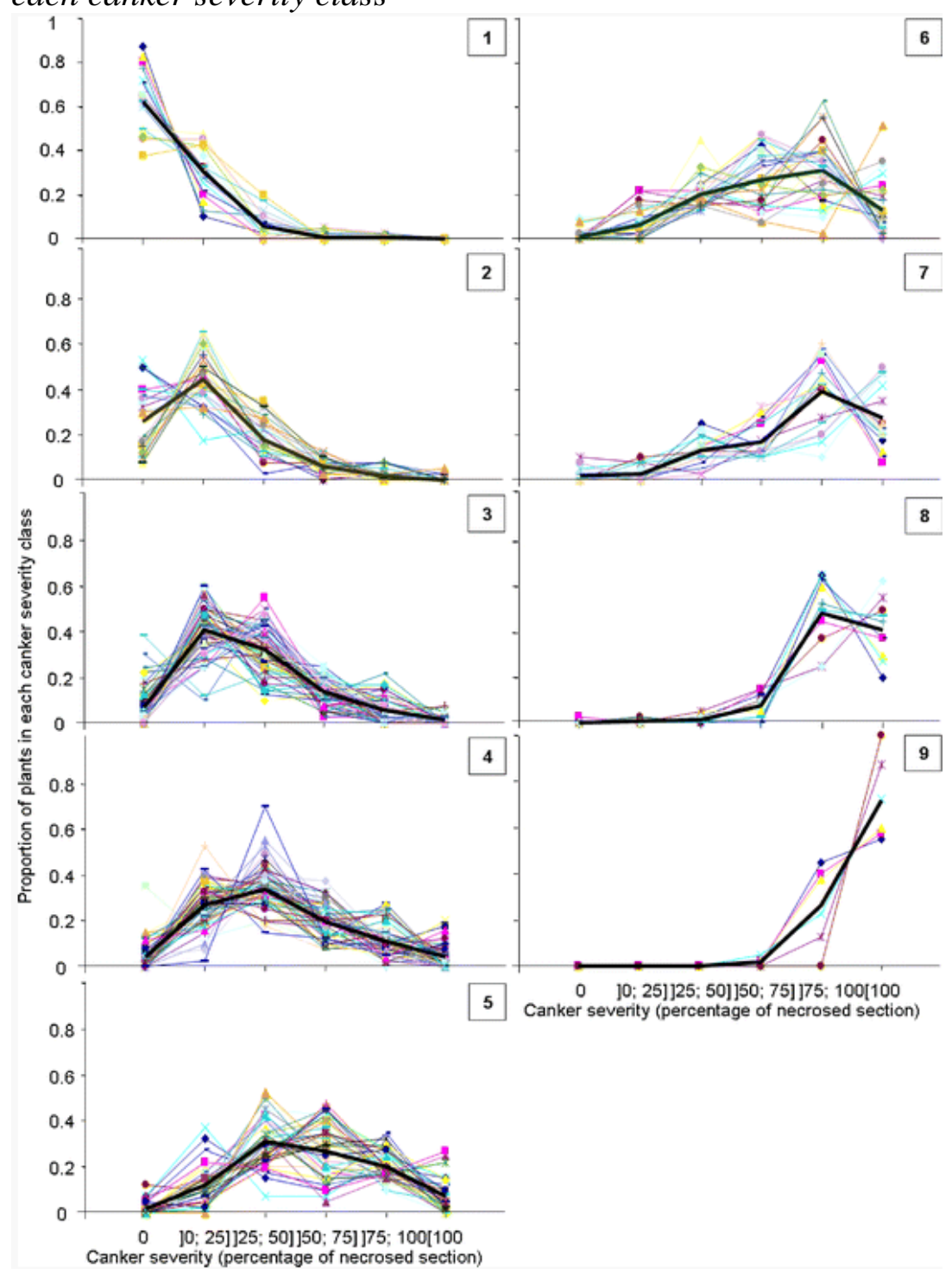

Fig. 2 Mean distributions for the different G2 DI-intervals (Table 2): each mean distribution represents the average of the proportion of plants of winter oilseed rape in each canker severity class

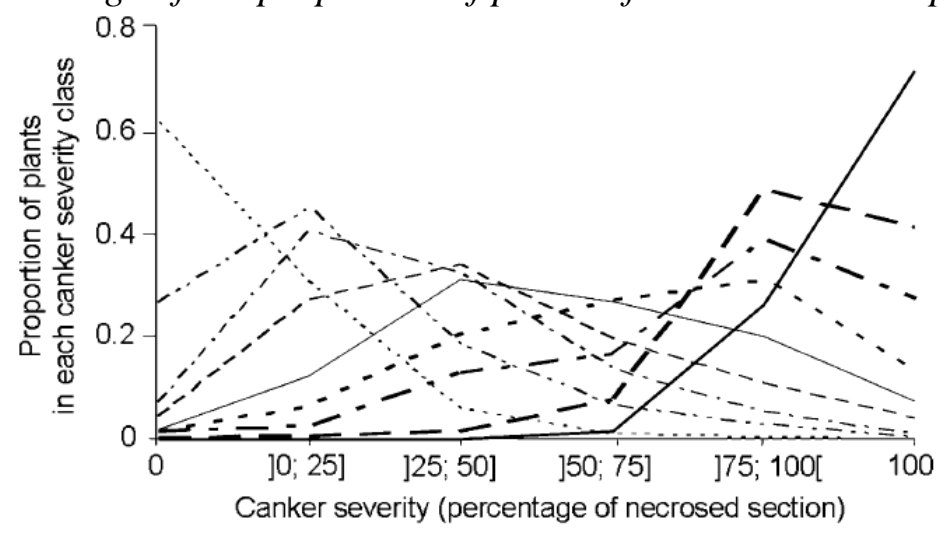

\begin{tabular}{|c|c|}
\hline $0<=G 2<=1$ & $\ldots \ldots \ldots \ldots . . . .52<=6$ \\
\hline$\cdots-1<\mathrm{G} 2<=2$ & $-\cdots 6<\mathrm{G} 2<=7$ \\
\hline $2<G 2<=3$ & $---7<\mathrm{G} 2<=8$ \\
\hline $3<G 2<=4$ & $-8<G 2<=9$ \\
\hline$-4<G 2<=5$ & \\
\hline
\end{tabular}




\section{Comparison with other severity disease indices}

The distribution for the disease index $\mathrm{DI}_{\mathrm{RH}}$ defined by Rempel and Hall (1996) corresponded to the proportion of plants in 5 classes of canker severity ( 0 to 4 ) instead of 6 for the G2 DI. The number of distributions in each analysed $\mathrm{DI}_{\mathrm{RH}}$-interval, all years and cultivars confounded, was 8 for the $\mathrm{DI}_{\mathrm{RH}}$-interval [0; 10[ (the values of $\mathrm{DI}_{\mathrm{RH}}$ in this interval corresponded to values of $\mathrm{G} 2$ of interval 1, Table 2), and 48 for the $\mathrm{DI}_{\mathrm{RH}}$-interval [50; 60[ (the values of $\mathrm{DI}_{\mathrm{RH}}$ in this interval corresponded to values of G2 of intervals 4 and 5, Table 2). Similarly to the G2 DI analysis, no distribution was significantly different from the corresponding average distribution with a threshold of $P=0.05$ and $P=0.1$ for the $\mathrm{DI}_{\mathrm{RH}}$-interval [0;10[, and one distribution was significantly different from its corresponding average distribution with a threshold of $P=0.1$ for the DI $\mathrm{RH}_{\text {-interval [50; 60[. }}$

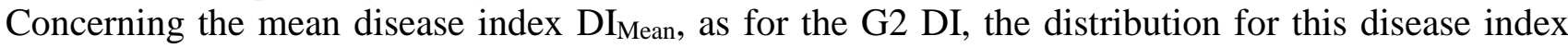
corresponded to the proportion of plants in 6 classes of canker severity ( 1 to 6$)$. The number of distributions in each analysed $\mathrm{DI}_{\mathrm{RH}}$-interval, all years and cultivars confounded, was 30 for the $\mathrm{DI}_{\text {Mean-interval [1; 2[ (the }}$ values of $\mathrm{DI}_{\text {Mean }}$ in this interval corresponded to values of G2 of intervals 1 and 2, Table 2), and 100 for the

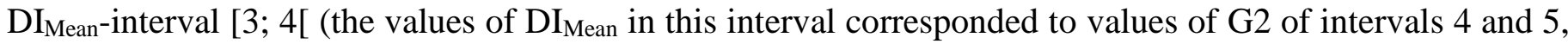
Table 2). Again, only one distribution was significantly different from its corresponding average distribution with a threshold of $P=0.1$ for the $\mathrm{DI}_{\text {Mean-interval }[1 ; 2[\text {, and three distributions were significantly different }}$ from their corresponding average distribution with a threshold of $P=0.1$ for the $\mathrm{DI}_{\text {Mean-interval }[3 ; 4[\text {. }}$

\section{Discussion}

The $\mathrm{G}_{2}$ DI, commonly used in France, is quite easy to calculate, and well correlated with yield losses (Aubertot et al. 2004b). As with all DI, the same value of $\mathrm{G}_{2}$ DI can be obtained with different distributions of plants in canker severity classes. In the example (Table 3), the value of G2 DI $=7.75$ was obtained for two different distributions of plants in each canker severities class. This variation in distributions observed in the field can be due to non-uniformity of reaction of resistant cultivar plants to systemic growth of the fungus, leading to various canker severities (Delourme et al. 2006). The presence of volunteers from different cultivars could also lead to such variation: the two different distributions leading to the same G2 DI value in Table 3 were obtained with two different cultivars, Eurol and Vivol. However, we showed that in field conditions, a given $\mathrm{G}_{2}$ DI range is more often obtained with similar distributions of canker severities. Very few distributions appeared different from the average distribution independently calculated, even in DI-intervals 8 and 9, where the number of distributions used to establish the average distributions was low (respectively 10 and 6 distributions). This study was also a way to test the robustness of the G2 DI, and the G2 DI seems to be a good indicator of observed distribution of canker severities. Mean distributions calculated for each G2 DI-interval were therefore used in SIPPOM-WOSR (Lô-Pelzer et al. 2008). The results found for mean distributions could be confirmed with additional data, particularly for highest intervals ( 8 and 9$)$, in other geographical and climatic contexts.

The same approach was applied to other disease indices used to assess the severity of phoma stem canker, the one proposed by Rempel and Hall (1996) $\mathrm{DI}_{\mathrm{RH}}$, and a simpler disease index DI Mean consisting of an average of the canker severity assessed on several plants. Similarly to the G2 DI, values of both disease indices tested were representative of the distribution of plants in each canker severity class for the analysed intervals. However, more distributions were significantly different from their corresponding average

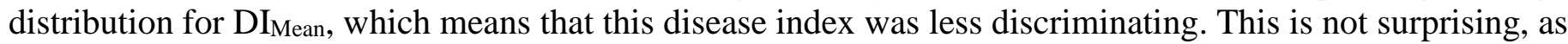
the range of values of this disease index was smaller, and distributions in each interval were therefore more numerous. The other disease indices analysed here could also have been used in SIPPOM, but an advantage of the G2 DI is that values are correlated to yield losses, whereas such a correlation is unknown for DI $\mathrm{RH}_{\mathrm{R}}$ and DIMean.

It would be interesting to test the effect of the existing variation in distribution of plants in canker severity classes on yield losses, particularly for distributions that are different from the corresponding average distribution. However, yield losses were not measured in experiments used for this study.

Associated with experimental results that describe the relationship between canker severity and quantity of primary inoculum produced (Lô-Pelzer et al., 2009), the mean distributions calculated for each G2 DI-intervals were used in the model SIPPOM-WOSR (Lô-Pelzer et al. 2008), to predict the potential quantity of primary inoculum from the $\mathrm{G} 2$ value of the previous year. 


\section{Acknowledgements}

The authors are grateful to GEVES and CETIOM for providing the data. This work is part of a Ph.D. project co-funded by INRA and CETIOM.

\section{References}

Aubertot, J. N., Schott, J. J., Penaud, A., Brun, H., \& Doré, T. (2004a). Methods for sampling and assessment in relation to the spatial pattern of phoma stem canker (Leptosphaeria maculans) in oilseed rape. European Journal of Plant Pathology, 110, 183-192. doi: 10.1023/B:EJPP.0000015359.61910.3b. Aubertot, J.N., Pinochet, X., Reau, R., \& Doré, T. (2004b). SimCanker: a simulation model for containing phoma stem canker of oilseed rape through cultural practices. (Proceedings of the 4th International Crop Science Congress. Brisbane, Australia)

Aubertot, J. N., West, J. S., Bousset-Vaslin, L., Salam, M. U., Barbetti, M. J., \& Diggle, A. J. (2006). Improved resistance management for durable disease control: A case study of phoma stem canker of oilseed rape (Brassica napus). European Journal of Plant Pathology, 114, 91-106. doi: 10.1007/s 10658-005-3628$\mathrm{z}$.

Brunin, B., \& Lacoste, L. (1970). Recherches sur la maladie du colza due à Leptosphaeria maculans (Desm.) Ces. et de Not., II: pouvoir pathogène des ascospores. Annals of Phytopathology, 2, 477-488.

Delourme, R., Chèvre, A. M., Brun, H., Rouxel, T., Balesdent, M. H., Dias, J. S., et al. (2006). Major gene and polygenic resistance to Leptosphaeria maculans in oilseed rape (Brassica napus). European Journal of Plant Pathology, 114, 41-52. doi: 10.1007/s10658-005-2108-9.

Hall, R. (1992). Epidemiology of blackleg of oilseed rape. Canadian Journal of Plant Pathology, 14, 46-55.

Harper, F. R., \& Berkenkamp, B. (1975). Revised growth-stage key for Brassica campestris and B. napus. Canadian Journal of Plant Science, 55, 657-658.

Lô-Pelzer, E., Aubertot, J. N., Bousset, L., Salam, M. U., \& Jeuffroy, M. H. (2008). SIPPOM-WOSR: $a$ Simulator for Integrated Pathogen Population Management to Design Control Strategies against Phoma Stem Canker on Winter Oilseed Rape, Maintaining the Efficiency of Specific Resistances. Italy: Proceedings of the X ESA Congress. Bologna.

Lô-Pelzer, E., Aubertot, J. N., David, O., Jeuffroy, M. H., \& Bousset, L. (2009). Relationship between the severity of phoma stem canker (Leptosphaeria maculans/L biglobosa species complex) and subsequent primary inoculum production on oilseed rape stubble. Plant Pathology, 58, 61-70. doi: 10.1111/j.13653059.2008.01931.x.

McGee, D. C. (1973). How to assess the severity of blackleg disease and predict yield. Journal of Agriculture, Victoria, 71, 241-242.

Pierre, J. G., \& Regnault, Y. (1982). Contribution à la mise au point d'une méthode de plein champ destinée à mesurer la sensibilité des variétés de colza au phoma. Informations Techniques CETIOM, 81, 3-18.

Rempel, C. B., \& Hall, R. (1996). Comparison of disease measures for assessing resistance in canola (Brassica napus) to blackleg (Leptosphaeria maculans). Canadian Journal of Botany, 74, 1930-1936. doi: 10.1139/b96-230.

Van den Berg, C. G. J., Rimmer, S. R., \& Parks, P. (1993). Comparison of scales for rating severity of blackleg in canola. Canadian Journal of Plant Pathology, 15, 49-53.

Wallach, D., Makowski, D., \& Jones, J. W. (eds). (2006). Working with Dynamic Crop Models. Amsterdam: Elsevier.

West, J. S., Kharbanda, P. D., Barbetti, M. J., \& Fitt, B. D. L. (2001). Epidemiology and management of Leptosphaeria maculans (phoma stem canker) on oilseed rape in Australia, Canada and Europe. Plant Pathology, 50, 10-27. doi: 10.1046/j.1365-3059.2001.00546.x. 